\title{
A Questionnaire Survey of Quality Control of Flow Cytometry in Korea and Development of New Quality-Control Materials
}

Jae Seong Shim", Sang Mi Hwang ${ }^{2}$, In Suk $\mathrm{Kim}^{3}$, Sang Yong Shin ${ }^{4}$, Ju Young $\mathrm{Oh}^{1}$, Kyoung Joo Lee ${ }^{5}$, and SunYoung Kong ${ }^{1,5}$

${ }^{1}$ Department of Laboratory Medicine, National Cancer Center, Goyang; ${ }^{2}$ Department of Laboratory Medicine, Seoul National University Bundang Hospital, Seongnam; ${ }^{3}$ Department of Laboratory Medicine, Pusan National University Yangsan Hospital,

Yangsan; ${ }^{4}$ Department of Laboratory Medicine, Seoul Metropolitan Dongbu Hospital, Seoul;

${ }^{5}$ Department of Cancer Biomedical Science,

National Cancer Center Graduate School of Cancer Science and Policy, Goyang, Korea

Corresponding author: Sun-Young Kong

Department of Cancer

Biomedical Science, National Cancer Center Graduate School of Cancer Science and Policy, 323 Ilsan-ro, Ilsandong-gu, Goyang 10408, Korea

Tel: +82-31-920-1735

Fax: +82-31-920-1268

E-mail: ksy@ncc.re.kr
Background: There are few commercial quality-control (QC) materials for internal QC of flow cytometric analysis, especially for leukemia/lymphoma immunophenotyping. The purpose of this study was to investigate the current QC status of flow cytometry in Korea through a questionnaire survey, and develop new QC materials using cultured cell lines for markers which QC materials are unavailable.

Methods: The current state of internal QC of flow cytometry in Korea was investigated via a questionnaire survey. Cell lines to be used as QC materials were cultured and produced as QC materials. Cell viability and the expression of markers on the cultured cell lines were tested by flow cytometry to confirm the stability of the QC materials. Simulated quality assessment results for the cultured cell line QC materials were sent to laboratories for external proficiency testing (PT).

Results: Seventeen medical institutions completed the questionnaire survey. Hematopoietic stem cell count (CD34) and lymphocyte subset panel items in most of these institutions were managed using commercialized QC materials. The markers that could not be managed by QC materials were CD117, MPO (myeloperoxidase), TdT (terminal deoxynucleotidyl transferase), CD20, CD10, CD64, CD79 $\alpha$, FMC7, cytoCD22, CD23, CD34, and CD61. Five cell lines expressing these markers were selected and sent as QC materials. PT results for most of the markers were in concordance, except those for FMC7 and CD64.

Conclusions: For the QC control of flow cytometry without commercialized QC materials, cultured cell lines are useful and can be used as an alternative for management of reagents used in flow cytometric analysis.

(J Lab Med Qual Assur 2017;39:168-177)

Key Words: Flow cytometry, Laboratory Proficiency testing, Quality control

Received September 17, 2017, Revision received November 7, 2017, Accepted November 19, 2017

\section{서론}

유세포검사의 내부정도관리는 크게 검체, 시약, 분석기에 관 한 부분으로 나뉘며, 이 중 시약의 내부정도관리 부분은 시약
의 적절한 보관과 기록을 포함하여 시약의 성능을 검증하는 것 이다 [1,2]. 시약의 내부정도관리 시행은 정도관리물질의 사용, 기존의 시약과 평행검사, 환자 검체에 포함된 양성 대조물질을 이용을 통해 가능하다[3]. 유세포 분석기를 이용한 검사들은 


\section{Journal of LABORATORY MEDICINE and QUALITY ASSURANCE}

\section{Jae Seong Shim et al $\bullet$ Quality Control of Flow Cytometry}

다양하며 백혈병 및 림프종 면역표현형 검사, 림프구아형검사, $\mathrm{CD} 34$ 양성 세포 산출 등의 세포표지자검사가 대표적이라 할 수 있다. 다양한 세포표지자검사에서 정확한 검사결과를 위해 서는 올바른 정도관리가 요구된다. 유세포 분석시약의 내부정 도관리의 경우 정도관리물질이 필요한데, 상품화된 정도관리 물질을 이용하지 못할 경우에는 정상인의 전혈이나 분석할 검 체에 혼입된 림프구들을 따로 gating하여 이용할 수 있다. 또 한 CD34나 terminal deoxynucleotidyl transferase (TdT)처
럼 정상인 세포에 많이 표현되지 않는 세포표지자는 냉동보관 된 세포, 배양세포를 이용하기도 한다.

현재 여러 상품화된 유세포용 정도관리물질이 출시되고 있 으나 적용되는 세포표지자의 범위는 제한적이다[4]. 가장 많 이 적용되는 세포표지자는 림프구아형검사에 포함되는 $\mathrm{T}, \mathrm{B}$, $\mathrm{NK}$ 세포표지자와 조혈모세포표지자인 CD34로 이들의 정도 관리물질은 현재 유세포검사실에서 일반적으로 활용되고 있 다. 그러나 혈액암 관련 여러 세포표지자를 검사할 수 있는 정

\begin{tabular}{|c|}
\hline (A) 1차 설문문항 \\
\hline 설문문항 \\
\hline 1. 유세포 분석에서 현재 사용하고 있는 장비는 어떤 종류에 장비를 사용하고 계십니까? \\
\hline 2. 현재 귀하의 병원에서 검사하고 있는 유세포 분석 검사 종류는 어떤 것이 있습니까? \\
\hline 1. Stem cell count(CD34) \\
\hline 2. Lymphocyte Subset Panel \\
\hline 3. Leukemia Marker \\
\hline 3-1. Acute Leukemia Panel \\
\hline 3-2. Chronic Leukemia/Lymphoma Panel \\
\hline 3-3. Multiple Myeloma Panel \\
\hline 7. PNH Panel \\
\hline 8. Cell Cycle Analysis \\
\hline 9. MDS PANEL \\
\hline 10. 기타 (기타 시행 검사는 수기로 적어 주시길 바랍니다) \\
\hline 3. 현재 유세포 분석에서 사용하고 있는 Marker는 어떤 종류가 있습니까? (체크 또는 기록해 주세요) \\
\hline 4. 사용하고 있는 Marker에 대한 내부정도관리는 어떻게 하고 계십니까? \\
\hline $\begin{array}{l}\text { (1) 모든 항목을 정도관리를 하고있다. (4-1 문항으로) } \\
\text { (2) 모든 항목을 정도관리를 못하고 있다. (4-2 문항으로) }\end{array}$ \\
\hline 4-2. 사용하고 있는 Marker에 대하여 내부정도관리를 못하시는 경우 어떻게 하고 계신가요? \\
\hline (1) 상품화된 정도관리물질(사용 정도관리 물질명을 기술해주세요.) \\
\hline (2) 환자검체(골수,CSF등)를 이용한 검사자간 비교 test(or 검사실간 비교 test) \\
\hline (3) 세포주(cell line)을 이용(세포주 명을 기술해 주세요) \\
\hline (4) (1)번(2)번으로 부족한 Marker는 외부 정도관리로 대체하고 있다. \\
\hline (5) 기타방법(위 보기외에 기타 방법이 있으시면 기술해 주세요) \\
\hline 5. 사용하고 있는 CD Marker에 내부정도관리 시행주기는 어떻게 하고 계십니까?(중목체크 가능) \\
\hline (1) 각종 Panel, Marker는 한달이내 시행하고 있다.(해당 보기 선택일 경우 5-1 문항으로) \\
\hline (2) 각종 Panel, Marker는 매월 시행하고 있다.(해당 보기 선택일 경우 5-2 문항으로) \\
\hline (3) 각종 Panel, Marker는 분기별로 시행하고 있다.(해당보기선택일 경우 5-3 문항으로) \\
\hline (4) 각종 Panel, Marker는 반기별로 시행하고 있다.(해당 보기 선택일 경우 5-4 문항으로) \\
\hline (5) 각종 Panel, Marker는 1년단위로 시행하고 있다.(해당 보기 선택일 경우 5-5 문항으로) \\
\hline (6) 적절한 시점에 test가 발생시 발생 시점단위로 하고 있다.(해당 보기 선택일 경우 5-6 문항으로) \\
\hline 5-1. 한달이내 평가하고 계시다면 어떤 항목입니까? \\
\hline 5-2. 매월 평가하고 계시다면 어떤 항목입니까? \\
\hline 5-3. 분기별 평가하고 계시다면 어떤 항목입니까? \\
\hline 5-4. 반기별 평가하고 계시다면 어떤 항목에 검사와 Marker인지 기술해 주십시요 \\
\hline 5-5. 1년단위 평가하고 계시다면 어떤 항목에 검사와 Marker인지 기술해 주십시요 \\
\hline 5-6. 적절한 시점에 test가 발생시 발생 시점단위로 평가하고 계시다면 어떤 항목에 검사와 Marker인지 기술해 주십시요. \\
\hline 6. 현재 병원에서 사용중인 Marker중 내부정도관리 물질로 시행하지 못하는 Marker는 어떤 Marker 입니까? \\
\hline (번호 체크 또는 other인경우 기술해 주세요) \\
\hline
\end{tabular}

Fig. 1. Questionnaire survey items. 


\section{Journal of LABORATORY MEDICINE and QUALITY ASSURANCE}

\section{Jae Seong Shim et al $\bullet$ Quality Control of Flow Cytometry}

도관리물질은 거의 출시되지 않고 있어 주기적인 정도관리가 어렵다. 이러한 문제점으로 인해 주기적으로 혈액암의 정도관 리를 하기 위한 정도관리물질 개발이 요구되고 있다. 백혈병/ 림프종의 경우 다양한 면역표현형을 가지며 각 세포에 따라 특 이적으로 발현되는 면역표현형이 다르다. 대표적인 림프구계 백혈병/림프종 세포주에는 버킷림프종 유래 Daudi 세포주, 급 성림프모구백혈병 유래 NALM-1 및 MM1S 세포주가 있고 골수계 백혈병 세포주에는 급성골수성백혈병 유래 Kasumi-1
세포주, 급성단구세포백혈병 유래 THP-1 세포주 등이 있다 [5].

본 연구의 목적은 국내 유세포 분석의 내부정도관리 현황파 악을 통해 필요한 정도관리용 세포표지자를 설정하고, 이에 따 라 해당 항원을 가진 세포주를 이용하여 정도관리물질의 개발 을 시도함에 있다. 나아가 개발된 내부정도관리물질의 효능성 을 평가하고 유세포 분석의 내부정도관리지침을 제시하고자 한다.

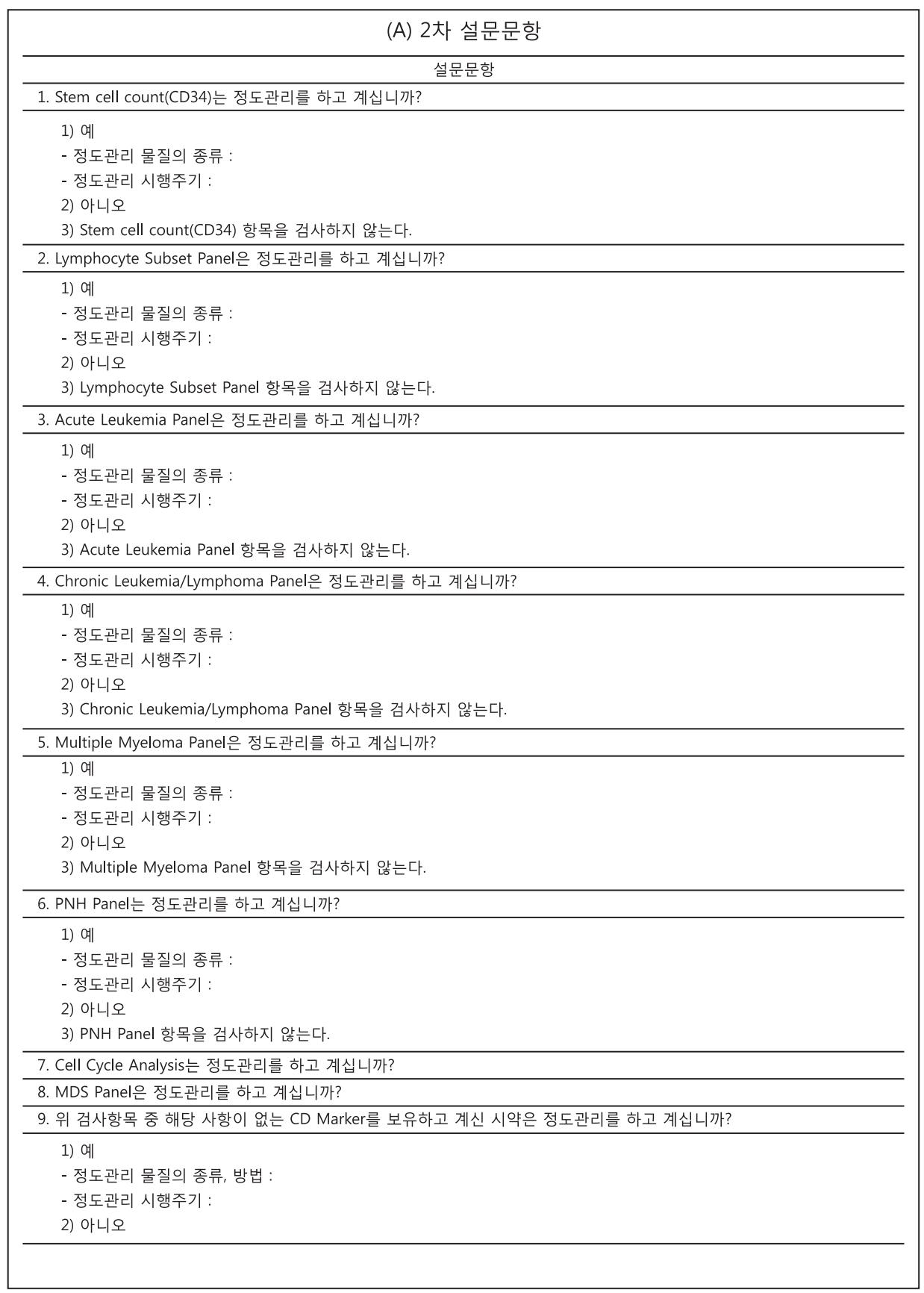

Fig. 1. Continued. 


\section{Journal of LABORATORY MEDICINE and QUALITY ASSURANCE}

\section{Jae Seong Shim et al • Quality Control of Flow Cytometry}

\section{재료 및 방법}

\section{1. 유세포검사 정도관리 현황파악을 위한 설문조사}

국내 유세포 분석이 가능한 42 개 의료기관 전문의에게 참여 의사를 문의하였고 참여를 원하는 검사실에 1 차 설문지를 발 송한 후 부족한 설문을 파악하여 2차 설문을 시행하였다(Fig. 1).

\section{2. 정도관리물질 제조 및 생존율 확인}

유세포 정도관리 설문조사결과에 의하여 정도관리를 시 행하지 못하는 항목 중 기관 수가 많은 세포표지자를 확인한 후 필요한 세포표지자는 한국 세포주은행과 American Type Culture Collection의 자료를 토대로 대표적인 세포주의 세포 표지자 발현 유무를 조사하였다(Table 1). 세포주는 한국 세 포주은행에서 구입하여 플라스크 $\left(\mathrm{T} 25 \mathrm{~cm}^{2}\right)$ 에서 $5 \% \mathrm{CO}_{2}$ 와 $95 \%$ 공기가 공급되는 $37^{\circ} \mathrm{C}$ 에서 배양하여 해당 세포표지자 를 실제로 발현하는지 확인한 후 대량 배양을 시작하여 정도 관리물질로 제조하였다. 각 물질의 세포표현형과 형광강도 등 의 결과 확인을 위해 제조된 정도관리물질을 세포수가 5-10× $10^{3} / \mu \mathrm{L}$ 가 되도록 $1 \mathrm{~mL}$ conical tube에 실온에서 72 시간 동안 보관 후, 세포 생존율을 각각 $24,48,72$ 시간에 Daudi, THP1, MM1S 세포주에 대해 7-amino-actinomycin D (AAD; Beckton Dickinson Biosciences, San Diego, CA, USA)를 이 용하여 검사하였다. 최대한 말초혈액과 유사한 형태를 유지하 기 위해 THP-1 세포주를 말초혈액과 혼합하여 보내는 경우, 세포주의 구분이 명확히 되는지를 CD45 allophycocyanin-H7 (BD Biosciences) 이용하여 검사 후 forward side scatter, side scatter (SSC) 그래프를 이용하여 분석하였다.

\section{3. 제작된 정도관리물질을 이용한 모의신빙도조사}

설문조사를 토대로 제작한 세포주 정도관리물질을 이용하 여 모의신빙도조사를 수행하고 결과를 분석하였다. 참여 의사 를 밝힌 검사실에 검사안내문, 5 가지 종류의 정도관리 검체,
유세포 결과 보고양식을 발송하였다. 신빙도조사 시 요청한 답 변은 장비현황, gating 정보, 각 세포주를 이용한 해당 $\mathrm{CD}$ 표 지자에 대한 항원분포 및 형광강도였다. 항원분포는 control population에 비교하여 유의하게 다르지 않은 경우 음성, control population에 비해 유의하게 다른 경우 양성, 일부만 양성인 경우 partially expressed로 표기할 것으로 정의를 제 시하였고, 형광강도는 가장 가까운 정상 hemato-lymphoid 집 단과 비교하여 중위 형광강도(median fluorescence intensity) 가 항원 양성 정상 집단에 비하여 낮은 경우 “dim," 비슷한 경 우 “intermediate," 밝은 경우를 "bright," 형광강도의 분포 가 퍼져 있는 경우 "heterogeneous"로 표기할 것을 제시하 였다. 세포표지자의 기관 간 일치도는 antigen distribution 결과 negative/positive를 기준으로 positive 결과를 일치, negative 결과를 불일치로 비교하였다. Partially expressed 는 positive로 간주하였다. 정도관리 검체는 세포주를 RPMI 1640 (Gibco, Grand Island, NE, USA) 배지와 섞어 배송하 였다.

\section{4. 세포주 정도관리물질을 이용한 내부정도관리 설정}

세포주를 이용한 내부정도관리 설정은 세포주를 대량 배양 한 후 세포주의 종류별로 나누어 저온냉동보관 $\left(-80^{\circ} \mathrm{C}\right)$ 후 3 개월 단위로 꺼내어 1 회씩 총 4 회 반복검사를 하고 얻은 데이 터로 평균 및 표준편차를 구하여 내부정도관리에 이용하였다. 정도관리 허용오차는 $\pm 2 \mathrm{SD}$ (standard deviation)를 이용하 였다.

\section{결과}

\section{1. 유세포검사 정도관리용 물질 제작을 위한 국내 정도관리 설문조사결과}

국내 유세포 분석이 가능한 42 개 의료기관 전문의에게 참여 의사 확인 결과 국립암센터를 포함한 17 개 기관에서 설문에

Table 1. Markers expressed on the different cell lines

\begin{tabular}{|c|c|c|c|c|c|c|c|c|c|c|c|c|c|c|c|}
\hline Cell line & CD117 & MPO & $\mathrm{TdT}$ & CD20 & CD10 & CD79a & FMC7 & CD38 & kappa & $\operatorname{IgM}$ & CD138 & CD11b & CD13 & CD64 & CD65 \\
\hline Kasumi & + & + & - & - & - & - & - & - & - & - & - & - & - & - & - \\
\hline Jurkat & - & - & + & - & - & - & - & - & - & - & - & - & - & - & - \\
\hline NALM-1 & - & - & + & - & - & - & - & - & - & - & - & - & - & - & - \\
\hline Daudi & - & - & - & + & + & + & + & + & + & + & - & - & - & - & - \\
\hline MM1S & - & - & - & - & - & - & - & - & - & - & + & - & - & - & - \\
\hline THP-1 & - & - & - & - & - & - & - & - & - & - & - & + & + & + & + \\
\hline
\end{tabular}

Abbreviations: CD, cluster of designation; MPO, myeloperoxidase; TdT, terminal deoxynucleotidyl transferase; IgM, immunoglobulin M. 


\section{Journal of LABORATORY MEDICINE and QUALITY ASSURANCE}

\section{Jae Seong Shim et al • Quality Control of Flow Cytometry}

참여 의사를 밝혔다. 유세포 정도관리 설문지 문항은 총 11 개 문항이고, 그 중 11 개 문항은 3 개 또는 4 개의 세부문항으로 구 성되어 이에 대한 답변 결과는 Table 2에 정리되었다.

유세포 분석에 사용되고 있는 세표표지자의 종류는 46종이 었으며 17 개 기관 중 $50 \%$ 이상 사용되고 있는 세표표지자는

Table 2. Summary of the questionnaire survey completed by 17 institutions

\begin{tabular}{lc}
\multicolumn{1}{c}{ Survey question items } & No. $(\%)$ \\
\hline Flow cytometry instrument used & $8(47.1)$ \\
Coulter FC & $3(17.6)$ \\
Coulter Navios & $1(5.9)$ \\
BD FACSCanto & $5(29.4)$ \\
BD FACSCanto II & \\
Tests performed with flow cytometry & $16(94.1)$ \\
Stem cell count & $16(94.1)$ \\
Lymphocyte subset panel & $14(82.4)$ \\
Leukemia panel & $13(76.5)$ \\
Acute leukemia panel & $10(58.8)$ \\
Chronic leukemia panel & $10(58.8)$ \\
Paroxysmal nocturnal hemoglobinuria panel & $7(41.2)$ \\
Multiple myeloma panel & $4(23.5)$ \\
Myelodysplastic syndrome panel & $1(5.9)$ \\
Cell cycle analysis & \\
Internal quality control performed for all markers & $8(47.1)$ \\
Yes & $9(52.9)$ \\
No & \\
\hline
\end{tabular}

The instruments used were from the following companies: $\mathrm{BD}$ (Beckton Dickinson Biosciences, San Diego, CA, USA) and Coulter (Beckman Coulter, Brea, CA, USA).
23종이었다(Fig. 2). 사용하고 있는 세표표지자의 내부정도관 리의 여부를 묻는 설문문항에서는 모든 항목을 정도관리를 하 고 있지 못하다는 문항에 $52.9 \%$ 가 응답을 하였고 모든 항목을 정도관리하고 있다는 문항은 $47.1 \%$ 가 응답을 하였다.

면역표현형 검사에서 시약 정도관리를 하지 못하는 표지 자 중 빈도가 높은 것은 $\mathrm{CD} 117$ (76.5\%), myeloperoxidase (MPO, 70.6\%), TdT (58.8\%), CD20 (52.9\%), CD10 (47.1\%), CD64 (47.1\%), CD79 $(47.1 \%)$, FMC7 (47.1\%), $\mathrm{CD} 34$ (41.2\%), CD38 (35.3\%)의 순으로 나타났다. 따라서 정도관리물질의 개발이 필요한 주요 항목은 시판 정도관리 물질이 보급된 $\mathrm{CD} 34$ 를 제외한 $\mathrm{CD} 117, \mathrm{MPO}, \mathrm{TdT}, \mathrm{CD} 20$, $\mathrm{CD} 10, \mathrm{CD} 64, \mathrm{CD} 79 \alpha, \mathrm{FMC7}, \mathrm{CD} 38$ 으로 판단되었다. 관련 된 세포주들의 항원발현을 검토한 결과 HL-60과 Kasumi-1 는 CD117과 MPO 발현, Jurkat과 NALM-1는 TdT 발 현, Daudi 세포주는 CD20, CD10, CD79 $\alpha, \mathrm{FMC7}, \mathrm{CD} 38$, kappa, immunoglobulin M (IgM) 발현, MM1S 세포주는 CD138 발현, THP-1 세포주는 CD11b, CD13, CD64, CD65 발현을 확인하였다. 최종적으로 Daudi, Kasumi- 1 , THP- 1 , NALM-1, MM1S 세포주를 선택하여 정도관리물질을 제조하 였다.

\section{2. 정도관리물질 제조 결과}

Daudi 세포주의 CD10, CD11b, CD13, CD20, CD38, cCD79 , kappa, FMC7 발현실험을 위해 한국 세포주은행 에서 제공된 배양방법으로 세포주 배양 이후 유세포 분석에 필요한 적정 세포수량 $\left(5-10 \times 10^{3} / \mu \mathrm{L}\right)$ 으로 계산하여 발현실 험을 진행하였다. 시약은 CD10 fluorescein isothiocyanate (FITC), CD11b FITC, CD13 FITC, CD20 FITC, CD38 FITC, cCD79 $\alpha$ phycoerythrin, kappa FITC, FMC7 FITC

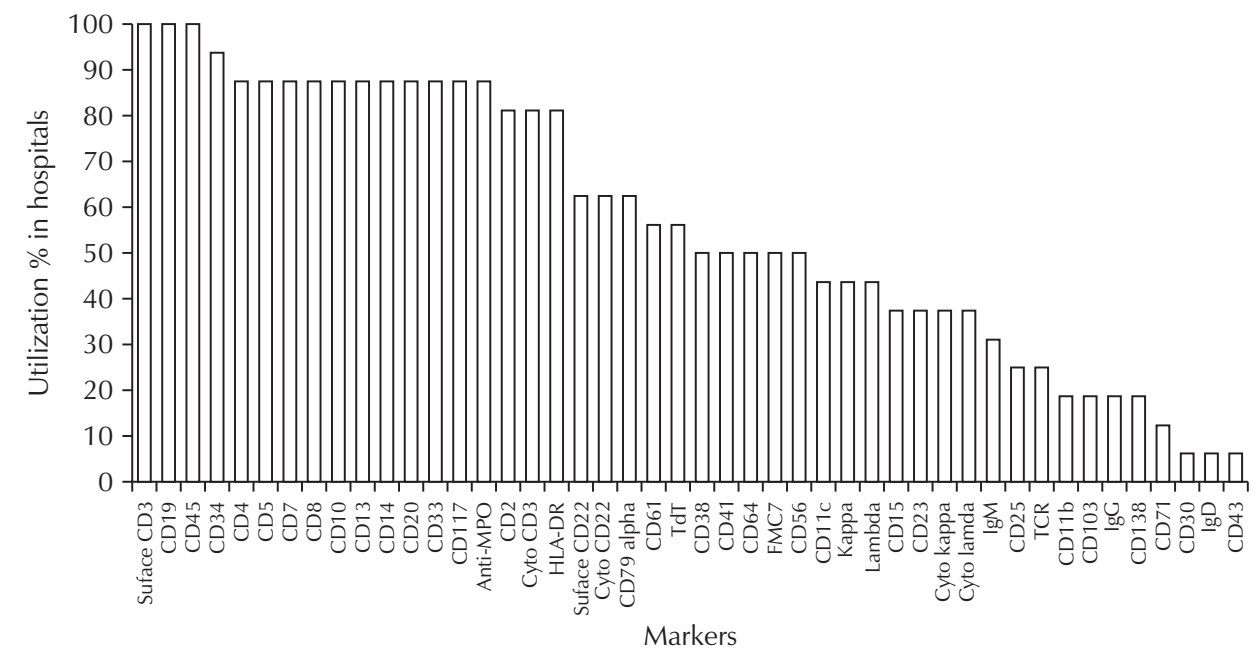

Fig. 2. Cell markers tested in 17 institutions that replied to the survey. Abbreviations: $\mathrm{CD}$, cluster of designation; MPO, myeloperoxidase; Cyto, cytoplasmic; TdT, terminal deoxynucleotidyl transferase; IgM, immunoglobulin M; TCR, T cell receptor; IgG, immunoglobulin G; IgD, immunoglobulin D. 


\section{Journal of LABORATORY MEDICINE and QUALITY ASSURANCE}

\section{Jae Seong Shim et al • Quality Control of Flow Cytometry}

(BD Biosciences)를 사용하였으며 FACSCanto II (BD Bioscience)를 이용하여 분석하였다. 선별한 세포주들은 알려 진 발현형과 결과가 일치하였다. 세포주들을 배양 후 RPMI 1640와 phosphate-buffered saline (pH 7.4)에 보관하여 실 온에서 3일 동안 Daudi, THP-1, MM1S 세포주의 세포생존도 를 조사한 결과(Table 3), 72시간 경과 실온 생존율은 $65.7 \%$ 에서 $100.0 \%$ 로 다양하게 나타났다. 세포주와 말초혈액을 혼 합하여 $\mathrm{CD} 45 / \mathrm{SSC}$ 상에서 비정상세포인 세포주가 명확히 구 분되는지 확인하였는데, THP-1 세포주는 단핵구 위치 위쪽에 존재하는 것을 확인하여 정상 단핵구와 겹치는 소견을 보여 말 초혈액 혼합 검체보다는 세포주만 정도관리물질로 발송하게 되었다.

\section{3. 제작된 정도관리물질을 이용한 모의신빙도조사 결과}

설문조사에 응한 17 개 기관 중 13 개 기관이 외부정도관리 참여의사를 밝혔다. 이번 외부정도관리용 검체 중에서 가장 많은 세포표지자를 검사할 수 있었던 Daudi 세포주 결과는 FMC7 항목을 제외하고는 모두 양성 결과를 보였다(Table 4). $\mathrm{Dim}$ 으로 결과를 표기한 antigen은 CD10, FMC7, surface $\mathrm{IgM}$ 이며 각각 1기관이었고 heterogeneous로 표기한 antigen 은 CD20이며 1 개 기관이었다. Kasumi 세포주는 2개의 항목 에 대한 검사를 진행하였고 $\mathrm{MPO}, \mathrm{CD} 117$ 모두 양성을 보였 다. Dim와 heterogeneous으로 결과를 표기한 antigen은 각 각 1 개 기관이었다. NALM-1 세포주는 TdT를 검사하였고 4 개 기관은 검사가 시행되지 않았으며 검사를 시행한 9 개 기관 모두 양성을 보였다. Dim으로 결과를 표기한 기관은 4 개 기 관이며 heterogeneous으로 표기한 기관은 1 개 기관이었다. 1 개 기관이 partially expressed로 보고하였다. MM1S 세포주 는 $\mathrm{CD} 138$ 에 대한 검사를 진행하였고 1 개 기관은 검사가 시 행되지 않았으며 검사를 시행한 12 개 기관 모두 양성을 보였 다. 2개 기관이 partially expressed로 보고하였다. Dim으로 결과를 표기한 기관은 2 개 기관이며 heterogeneous으로 표기
한 기관도 2 개 기관이었다. THP-1 세포주는 CD11b, CD13, $\mathrm{CD} 64, \mathrm{CD} 65$ 항목을 시행하였고 $\mathrm{CD} 11 \mathrm{~b}$ 항목은 10 개 기관은 검사가 시행되지 않았으며 검사를 시행한 3개 기관 모두 양성 이었고, 1 개 기관이 partially expressed로 보고하였다. CD13 항목은 13 개 기관 모두 양성으로 보고하였고 CD64 항목은 4 개 기관이 시행하지 않았으며 1 개 기관이 음성으로 보고하였 다. Dim으로 결과를 표기한 기관은 1 개 기관이었다. CD65 항 목은 11 개 기관이 시행하지 않았고 2 개 기관이 양성으로 보고 하였다.

\section{4. 제작된 정도관리물질을 이용한 내부정도관리}

제작된 정도관리물질은 lot 번호별로 구별하여 저온냉동보 관 $\left(-80^{\circ} \mathrm{C}\right)$ 후 분기별로 총 4 회를 검사하고 평균 및 표준편차 를 구하여 내부정도관리에 이용하였다(Table 5). 혈액암 관련 여러 세포표지자를 검사할 수 있는 정도관리물질은 거의 출시 되지 않고 있어 주기적인 정도관리가 어려웠으나 제작된 정도 관리물질을 이용하여 정도관리를 할 수 있었다.

\section{고찰}

국내 17 개 의료기관 설문조사를 한 결과 17 개 의료기관 중 대부분의 의료기관은 CD34 양성세포 측정과 림프구아형검사 는 상품화된 정도관리물질을 사용하여 정도관리를 하고 있었 다. 하지만, 혈액종양 진단과 모니터링에 요구되는 유세포 분 석의 정도관리는 일부 세포표지자만 정도관리가 가능하여 정 도관리를 할 수 없는 세포표지자들은 외부정도관리 또는 환자 검체를 통해 정도관리를 하고 있는 실정이었다. 각 의료기관 의 검사항목별 정도관리 분석시점은 동일하지 않으며 각 병원 의 특성에 맞게 정도관리 주기를 정해서 시행하고 있었다. 설 문조사 중 정도관리를 하지 못하는 높은 빈도를 보이는 세포 표지자는 CD117, MPO, TdT, CD20, CD10, CD64, CD79 $\alpha$, $\mathrm{FMC7}$, cytoCD22, CD23, CD34, CD61으로 조사되었고, 이

Table 3. Viability of the cell lines kept at room temperature

\begin{tabular}{clccc}
\hline Cell line & Marker & 24-hour cell viability (\%) & 48-hour cell viability (\%) & 72-hour cell viability (\%) \\
\hline Daudi & 7-AAD & 89.0 & 73.9 & 65.7 \\
& CD20 & 99.6 & 99.6 & 98.9 \\
THP-1 & 7-AAD & 86.9 & 88.9 & 88.3 \\
& CD64 & 99.9 & 100.0 & 100.0 \\
MM1S & 7-AAD & 98.2 & 90.5 & 71.9 \\
& CD138 & 98.8 & 94.2 & 86.1 \\
\hline
\end{tabular}

The reagents used were from the following companies: Beckton Dickinson Biosciences, San Diego, CA, USA.

Abbreviations: AAD, amino-actinomycin D; CD, cluster of designation. 


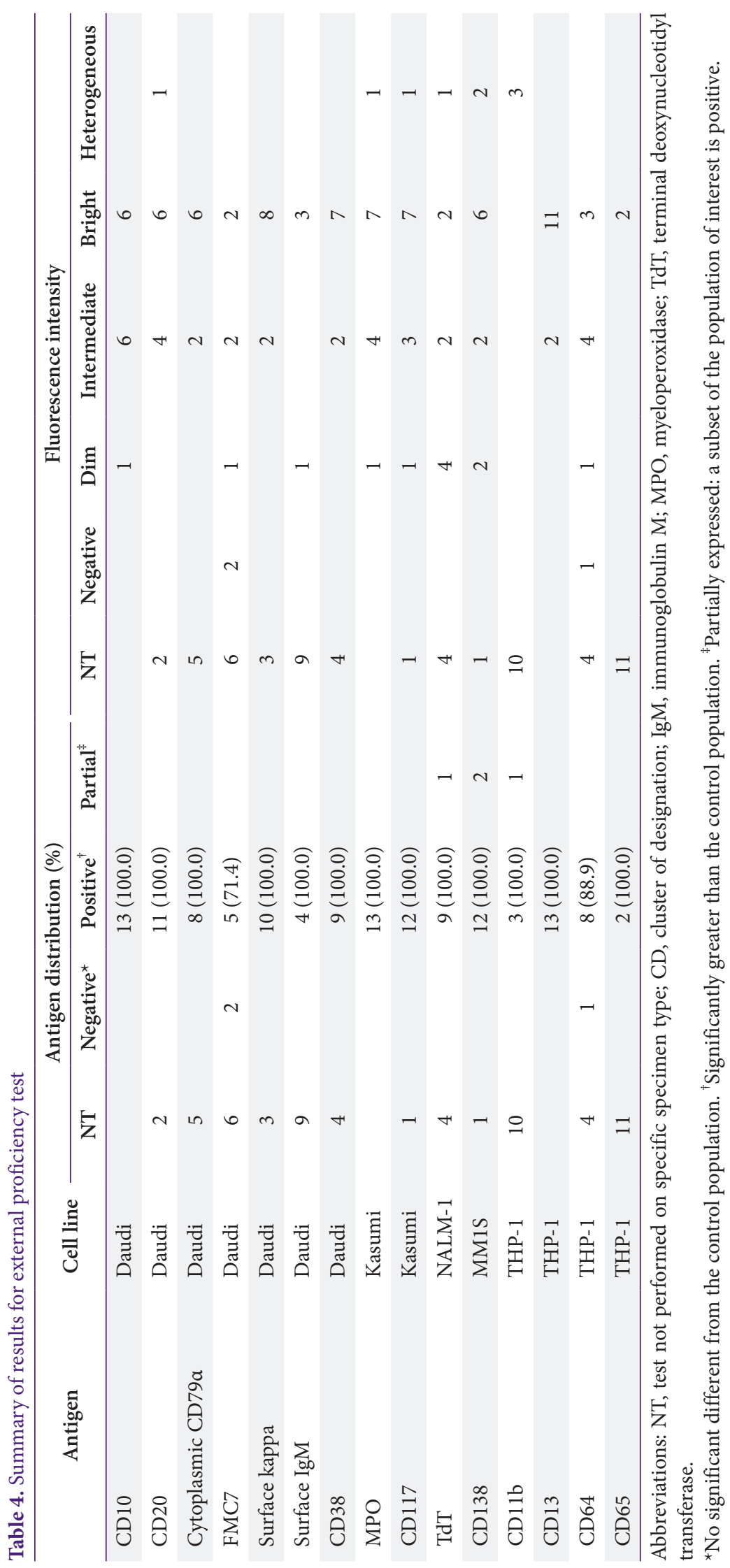


Journal of LABORATORY MEDICINE and QUALITY ASSURANCE

Jae Seong Shim et al • Quality Control of Flow Cytometry

Table 5. Quality control of flow cytometry reagents, using cultured cell lines

\begin{tabular}{cllcccccc}
\hline Antigen-fluorescence & Cell type & Vendor & Antigen expression & Percentage & Results & Mean \pm SD & \pm 2 SD range & Acceptability \\
\hline CD10-FITC & Daudi & BD & + & 98.9 & + & $85.2 \pm 6.5$ & $72.2-98.2$ & Ok \\
CD10-APC & Daudi & BD & + & 98.9 & + & $95.6 \pm 2.1$ & $91.4-99.8$ & Ok \\
CD13-PC5 & THP-1 & Coulter & + & 99.9 & + & $97.7 \pm 0.7$ & $96.3-99.1$ & Ok \\
CD20-FITC & Daudi & BD & + & 99.6 & + & $99.5 \pm 0.3$ & $98.9-100.0$ & Ok \\
CD20-PE & Daudi & BD & + & 99.6 & + & $99.8 \pm 0.1$ & $99.6-100.0$ & Ok \\
\hline
\end{tabular}

The reagents used were from the following companies: BD (Beckton Dickinson Biosciences, San Diego, CA, USA) and Coulter (Beckman Coulter, Brea, CA, USA).

Abbreviations: SD, standard deviation; FITC, fluorescein isothiocyanate; APC, allophycocyanin; PE, phycoerythrin.

러한 세포표지자들은 혈액종양 진단에 있어 중요한 세포표지 자들이지만 아직까지 이러한 세포표지자들의 시약을 정도관 리할 수 있는 물질이 개발되어 있지 않음을 확인할 수 있었다.

환자의 골수 검체가 아닌 세포주를 대량 배양하여 저온 냉동 보관 $\left(-80^{\circ} \mathrm{C}\right)$ 하면 일정한 주기로 꺼내어 필요시마다 정도관리 에 이용 가능할지 확인한 결과, 분기별로 총 4 회를 측정한 결 과 일정한 데이터를 확인할 수 있었으며 평균과 표준편차를 이 용하여 내부정도관리에 이용할 수 있었다. 일정하게 발현되는 세포주를 이용하여 외부신빙도 모의조사에서 여러 기관에서 일치하는 결과를 얻었기 때문에 제작된 세포주를 정도관리물 질로 이용함에 문제가 없음을 알 수 있었다 [6-8]. 또한 각 기관 별로 시약, 장비조건, 환경이 유지된다면 일정한 세포표현형을 확인할 수 있으므로, 데이터를 누적하여 평균과 표준편차를 이 용하여 내부정도관리를 할 수 있는 방안을 제시하였다고 볼 수 있다 $[9,10]$.

세포주를 이용한 시약의 정도관리물질 제조 시에는 정도관 리물질 배포 시 구성액에 대한 고려, 적절한 세포수 수확, 생존 율 및 배송에 대한 고려가 필요하여 이에 대한 실험을 진행하 였고[11], 상품화된 정도관리물질로 모든 시약을 관리할 수 없 는 현재의 상황에서 세포주의 특이적 발현을 이용하여 세포주 를 내부정도관리물질로 사용한다면 정도관리를 하지 못한 문 제에 대한 해결방안이 될 것으로 생각된다.

\section{감사의 글}

이 연구는 2016년 진단검사의학재단의 학술연구과제 지원 으로 수행되었다(연구과제: 1641260-1). 연구에 참여해 주신 아래 기관의 전문의 선생님들께 감사드린다(존칭 생략).

가천대학교 길병원 안정열, 고려대학교안산병원 남명현, 녹 십자의료재단 배혜경, 인제대학교부산백병원 이자영, 동국대 학교일산병원 허희진, 동아대학교병원 한진영, 삼성서울병원 조덕, 양산부산대학교병원 김인숙, 분당차병원 허지영, 서울대
학교병원 이동순, 서울아산병원 박찬정, 아주대학교병원 조성 란, 원광대학교병원 박도심, 원자력병원 장윤환, 이대목동병원 허정원, 충남대학교병원 김선영

\section{REFERENCES}

1. Laboratory Medicine Foundation. Laboratory accreditation program checklist: diagnostic immunology. Seoul: Laboratory Medicine Foundation, 2017.

2. College of American Pathologists. CAP accreditation checklists: flow cytometry. Chicago (IL): College of American Pathologists, 2016.

3. Wood B, Jevremovic D, Bene MC, Yan M, Jacobs P, Litwin $\mathrm{V}$, et al. Validation of cell-based fluorescence assays: practice guidelines from the ICSH and ICCS: part V. assay performance criteria. Cytometry B Clin Cytom 2013;84:315-23.

4. Owens MA, Vall HG, Hurley AA, Wormsley SB. Validation and quality control of immunophenotyping in clinical flow cytometry. J Immunol Methods 2000;243:3350 .

5. Drexler HG. Guide to leukemia-lymphoma cell lines. 2nd ed. Braunschweig: DSMZ, 2010.

6. Mizrahi O, Ish Shalom E, Baniyash M, Klieger Y. Quantitative flow cytometry: concerns and recommendations in clinic and research. Cytometry B Clin Cytom 2017 Feb 11 [Epub]. https://doi.org/10.1002/cyto.b.21515.

7. Siftar Z, Paro MM, Sokolic I, Nazor A, Mestric ZF. External quality assessment in clinical cell analysis by flow cytometry: why is it so important? Coll Antropol 2010; 34:207-17.

8. Kluin-Nelemans J, van Wering E, van der Schoot C, 


\section{Journal of LABORATORY MEDICINE and QUALITY ASSURANCE}

Jae Seong Shim et al $\bullet$ Quality Control of Flow Cytometry

Adriaansen H, van't Veer M, van Dongen J, et al. SIHONSCORE: a scoring system for external quality control of leukaemia/lymphoma immunophenotyping measuring all analytical phases of laboratory performance. $\mathrm{Br} \mathrm{J}$ Haematol 2001;112:337-43.

9. Lock RJ. My approach to internal quality control in a clinical immunology laboratory. J Clin Pathol 2006; 59:681-4.

10. Kwon GC, Kim J, Ra GS; Diagnostic Hematology Sub- committee; Korean Association of External Quality Assessment Service. Annual report on the external quality assessment for diagnostic hematology in Korea (2015). J Lab Med Qual Assur 2016;38:1-10.

11. Drexler HG. Isolation and culture of leukemia cell lines. In: Langdon SP, editor. Cancer cell culture: methods in molecular medicine. Totowa (NJ): Humana Press, 2004:141-55. 
유세포검사 내부정도관리의 현황파악 및 세포주를 이용한 유 세포검사 내부정도관리물질 개발

심재성 $\bullet$ 황상미 ${ }^{2}$ - 김인숙 ${ }^{3}$ 신상용 ${ }^{4}$ 오주영 ${ }^{1}$ 이경주 $^{5} \cdot$ 공선영 $^{1,5}$

${ }^{1}$ 국립암센터 진단검사의학과, ${ }^{2}$ 분당서울대학교병원 진단검사의학과, ${ }^{3}$ 양산부산대학교병원 진단검사의학과,

${ }^{4}$ 서울특별시동부시립병원 진단검사의학과, ${ }^{5}$ 국립암센터 국제암대학원대학교 암의생명과학과

배경: 유세포 분석의 내부정도관리에 있어 시판되고 있는 정도관리물질은 적으며, 특히 백혈병/림 프종 면역표현형 검사에 사용할 수 있는 시판된 정도관리물질은 거의 없다. 이 연구는 설문조사를 통해 국내 유세포 분석의 내부정도관리 현황을 파악하고, 내부정도관리가 어려운 세포표지자에 대 해 세포주를 이용한 내부정도관리물질을 개발하는 것이다.

방법: 국내 유세포 분석 내부정도관리 현황을 조사하기 위해 유세포 정도관리 설문조사를 시행하 여 국내 유세포 내부정도관리 현황을 파악하였다. 정도관리물질로 사용할 세포주를 구매한 후 배양 하여 정도관리용 물질을 제조하였다. 배양된 세포를 유세포 분석을 시행하여 세포 생존율과 세포표 면 항원의 발현 정도를 확인하여 정도관리물질로서의 안정성을 확인하였다. 이렇게 제작된 정도관 리물질을 이용한 모의신빙도조사 외부정도관리를 시행하였다.

결과: 국내 17 개 의료기관에서 설문조사에 응답하였고 대부분의 의료기관은 CD34 조혈모세포 수 측정과 림프구아형검사 항목은 상품화된 정도관리물질을 사용하여 정도관리를 하고 있었다. 설 문조사에서 정도관리 미시행의 빈도가 높은 세표표지자는 CD117, MPO (myeloperoxidase), TdT (terminal deoxynucleotidyl transferase), CD20, CD10, CD64, CD79alpha, FMC7, cytoCD22, CD23, $\mathrm{CD} 34, \mathrm{CD} 61$ 로 조사되었다. 이 표지자를 표현하는 5개의 세포주를 선별하여 배양 후 정도관리물 질로 제조 후 모의신빙도 외부정도관리를 시행하였다. 대부분의 기관에서 FMC7과 CD64를 제외한 나머지 세포표지자에 대해 일치된 결과를 보였다.

결론: 상품화된 정도관리물질이 없는 유세포검사의 정도관리를 위해 제조된 세포주는 유세포 정도 관리에 유용하고 유세포검사의 시약 내부정도관리용으로 사용될 수 있을 것이다.

(J Lab Med Qual Assur 2017;39:168-177)

교신저자: 공선영

우)10408 고양시 일산동구 일산로 323, 국립암센터 진단검사의학과, 국제암대학원 대학교 암의생명과학과 Tel: 031)920-1735, Fax: 031)920-1268,E-mail: ksy@ncc.re.kr 